\title{
OPTIMALISASI PENCAHAYAAN ALAMI PASAR MODERN BINTARO DI KOTA TANGERANG SELATAN
}

\author{
Ratriana Said Bunawardi ${ }^{1}$, Cut Aisyah' ${ }^{2}$, Burhanuddin ${ }^{3}$ \\ 1,2,3 Jurusan Teknik Arsitektur \\ Fakultas Sains dan Teknologi UIN Alauddin Makassar \\ Jl. Sultan Alauddin No. 63, Gowa, Sulawesi Selatan. 92113 \\ E-mail: ratriana@gmail.com; cutaisyah9@yahoo.co.id; \\ burhanuddin.amin@uin-alauddin.ac.id
}

\begin{abstract}
Abstrak: Pencahayaan menjadi elemen penting dari suatu ruang dan bangunan. Perencanaan dan pertimbangan pencahayaan bangunan yang tidak matang dapat menimbulkan pencahayaan yang kurang baik ataupun tidak memenuhi standar fungsi ruang, terutama ruang publik seperti pasar. Pencahayaan alami yang berlebihan dapat memicu masalah baru seperti naiknya suhu rata-rata dalam bangunan. Sebaliknya keadaan ruang yang kekurangan pencahayaan juga dapat memicu masalah, seperti mengganggu kinerja mata maupun kenyamanan pengguna. Tujuan dari penelitian ini untuk mengetahui unsur penting pencahayaan di Pasar Modern Bintaro, dimana desain bangunannya memilki konsep modern. Data pada penelitian ini, diperoleh melalui observasi lapangan, wawancara, dokumentasi pribadi, dan data-data yang sudah ada. Metode penelitian yang digunakan yaitu metode kualitatif yakni metode yang mengumpulkan data yang sifatnya alamiah dengan teknik observasi langsung. Analisis yang digunakan adalah analisis deskriptif. Hasil penelitian ini menggambarkan bangunan Pasar Modern Bintaro dengan desain modern mampu mengoptimalisasikan pencahayaan dari alam.
\end{abstract}

Kata Kunci: desain, pasar, pencahayaan, ruang

\section{PENDAHULUAN}

$\mathrm{P}$ asar merupakan sarana yang telah menjadi kebutuhan di masyarakat. Sebagai daerah yang cukup maju, Bintaro menyediakan kebutuhan pokok masyarakat dengan kemasan Pasar Modern Bintaro. Pembahasan dalam aspek kenyamanan pencahayaan dipilih dengan pertimbangan bahwa cahaya merupakan faktor penting bagi pengguna pasar, terutama pasar modern. Dalam berbelanja tentu kita membutuhkan pencahayaan yang baik, itulah mengapa pasar jarang dibuka hingga malam hari, kalaupun ada perlu pencahayaan yang optimal demi kenyamanan konsumen. Pada penelitian ini membahas mengenai optimalisasi pencahayaan alami di Pasar Modern Bintaro. Bangunan dengan pencahayaan alami yang dimaksud ialah pencahayaan dengan sumber cahaya langsung dari alam.

Perlu kiranya pertimbangan pencahayaan optimal pada ruang publik yang menjadi pusat sosial untuk transaksi jual beli. Kenyamanan pengguna ruang perlu diperhatikan. Pencahayaan alami selain memberi kenyamanan berbelanja juga dapat sebagai pemelihara kelembapan ruang. Ruang yang terpelihara kelembabannya dapat mencegah virus dan bakteri, sehingga menciptakan lingkungan yang sehat dan lebih hemat energi. Dengan menggunakan desain bangunan modern, fungsi utama sebuah pasar tidaklah 
berubah. Hanya saja, bangunan dieksplor untuk memberikan kesan modern dan kenyamanan lebih.

\section{METODE PENELITIAN}

Penelitian ini merupakan penelitian dengan pendekatan kualitatif deskriptif. Objek dalam penelitian ini adalah Pasar Modern Bintaro di Kota Tangerang Selatan. Lokasi pasar berada di jalan Bintaro Utama 9, Kecamatan Pondok Aren, Kota Tangerang Selatan, Banten. Tujuan dari penelitian ini untuk menggambarkan aktualisasi bangunan modern untuk pasar dengan pengoptimalan pencahayaan alami.

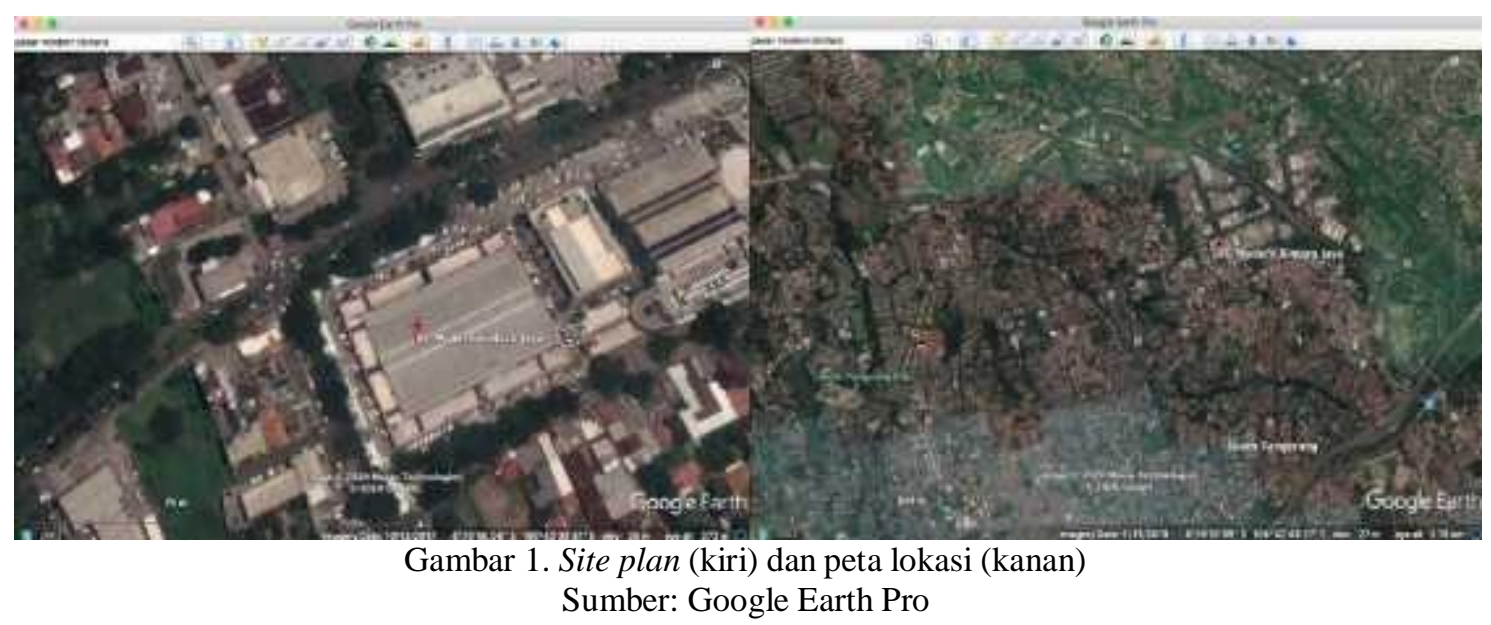

Metode pengambilan data yang digunakan ialah dengan observasi, survei lapangan atau peninjauan objek secara langsung, pengambilan dokumentasi dalam bentuk foto dan data-data yang telah ada untuk memenuhi kebutuhan penelitian.

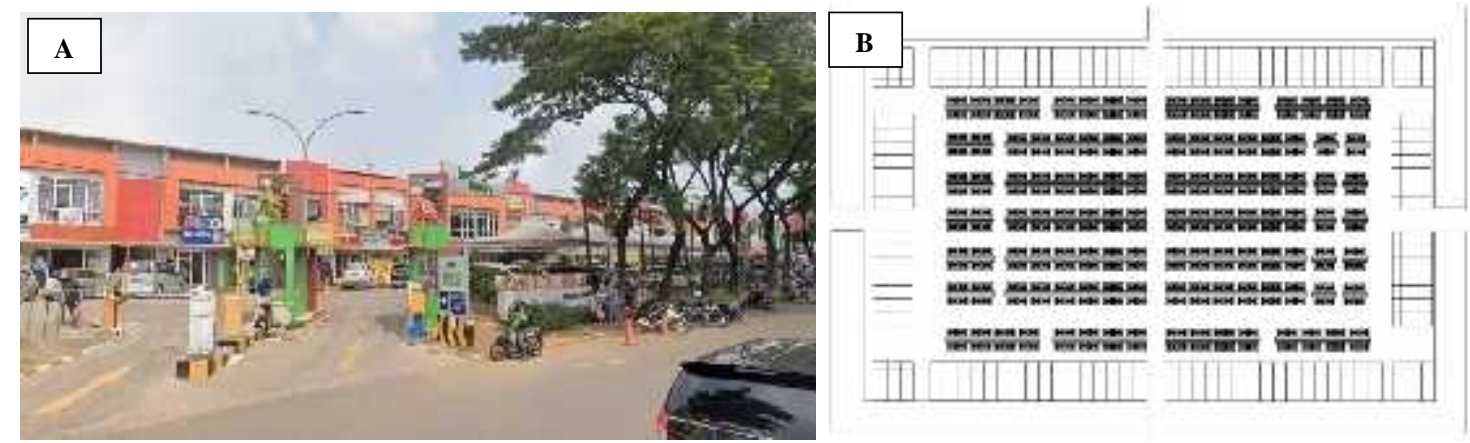

Gambar 2. Pasar Modern Bintaro (A) dan denah Pasar Modern Bintaro (B)

Sumber: https://www.google.com/maps/pasarmodernbintaro (A) dan hasil olah data penulis (B)

\section{HASIL DAN PEMBAHASAN}

Dalam prinsip pencahayaan dalam ruang, dibagi menjadi dua macam berdasarkan sumber energi yang dimanfaatkannya, yakni sistem pencahayaan alami dan sistem pencahayaan buatan. Kedua jenis ini memiliki kelebihan dan kekurangannya masingmasing. Pencahayaan dengan sistem alami ialah pencahayaan dengan memanfaatkan matahari. Pemanfaatan cahaya alami mempunyai banyak keuntungan, selain menghemat listrik juga dapat membunuh kuman dan bakteri yang tak terlihat. Hal ini merdampak baik bagi kesehatan lingkungan pasar. Untuk memanfaatkan pencahayaan alami, tentu kita memerlukan jendela, dinding, maupun atap yang memungkinkan 
cahaya untuk masuk ke dalam ruangan.

Disisi lain, pencahayaan alami juga memiliki kekurangan, diantaranya seperti kurang efektifnya pencahayaan akibat intensitas cahaya yang terkadang tidak menentu. Selain itu, sinar yang dihasilkan juga membawa hawa panas. Hawa panas dapat di atasi dengan perhitungan yang tepat, salah satunya yaitu dengan mengontrol intensitas cahaya matahari yang masuk menggunaan material yang tepat dan perhitungan sudut pemantulan cahaya yang tepat.

Pencahayaan alami termasuk kelompok arsitektur hemat energi. Pencahayaan alami juga termasuk klasifikasi arsitektur berkelanjutan, yaitu dengan memenuhi kebutuhan saat ini tanpa merusak ataupun memberi dampak negatif terhadap generasi selanjutnya. Hal ini merupakan salah satu bentuk upaya meminimalisir penggunaan energi secara berlebihan dan terus menerus. Untuk menanggulagi beberapa kekurangan penggunaan cahaya alami serta lebih efektif penggunaannya, perlu dikenali beberapa sumber cahaya utama yang dapat dimanfaatkan yaitu: (1) Sunlight, cahaya matahari langsung dengan tingkat cahaya yang tinggi; (2) Daylight, cahaya matahari yang umumnya tersebar dilangit dengan tingkat cahaya yang rendah; dan (3) Reflected light, cahaya matahari yang telah dipantulkan.

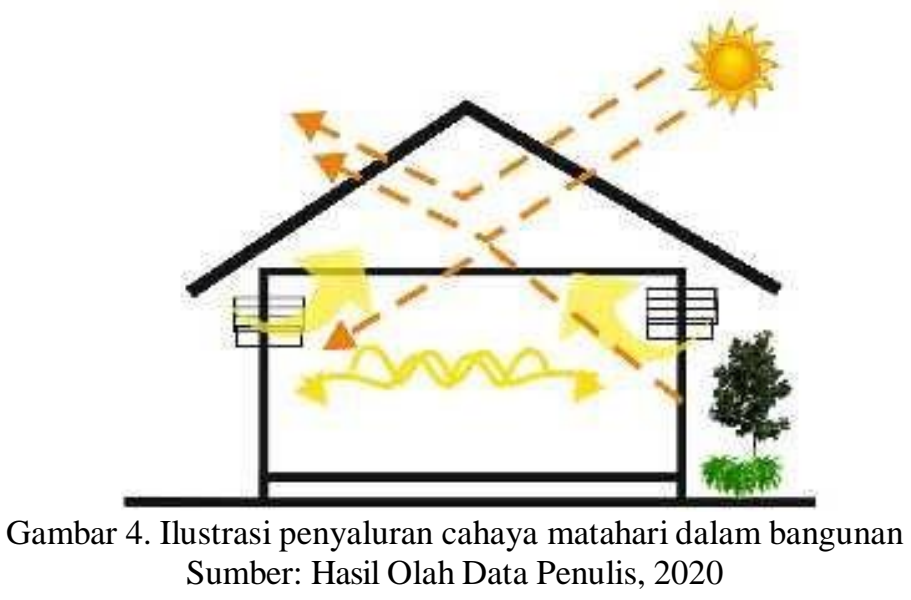

Pasar yang selama ini dikenal terbuka dengan penggunaan tenda-tenda kecil tanpa dinding, sekarang dikemas di dalam gedung satu atap yang cukup besar untuk menampung para penjual dan konsumen yang hendak berbelanja, inilah yang disebut pasar modern. Pasar modern ini tidak semerta-merta dibuat dengan gedung polos yang menutup semua bagian. Hal pokok selain penghawaan yang menjadi elemen penting sebuah pasar ialah pencahayaan. Berikut beberapa konsep yang diterapkan pada pencahayaan bangunan Pasar Modern Bintaro:

1. Perbedaan ketinggian atap yang kemudian diisi dengan kaca (material transparan) untuk memasukkan cahaya ke dalam ruang 


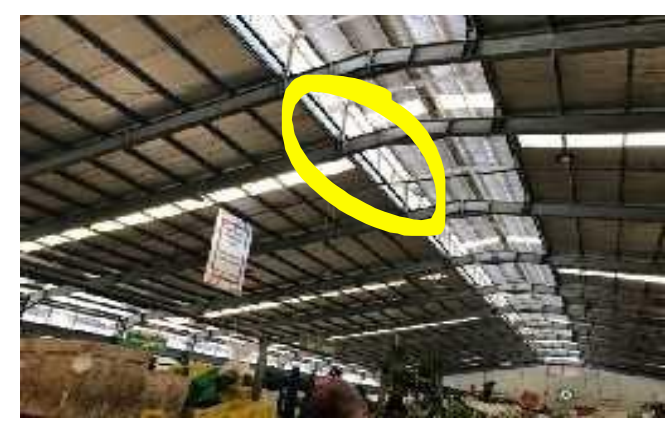

Gambar 5. Penampang tengah atap Pasar Modern Bintaro Sumber: Dokumentasi Pribadi, 2020

Salah satu cara pemanfaatan cahaya matahari secara optimal dengan memanfaatkan material transparan. Cahaya matahari masuk ke ruang dengan tetap dikontrol agar tidak menimbulkan silau ataupun keadaan yang terlalu panas. Atap juga dipasang cukup tinggi dengan pertimbangan melancarkan sirkulasi udara di dalam bangunan juga untuk memanfaatkan potensi cahaya alami.

2. Mengkombinasikan antara penutup atap seng dengan material transparan

Membuat cahaya dapat tersebar secara rata di setiap sudut ruang pada bangunan, terutama ke titik poin pada tengah bangunan yang juga ditempatkan sebagai pusat penjualan. Pada bagian lantai Pasar Modern Bintaro menggunakan bahan keramik. Konstruksi dinding menggunakan bata yang ditutup plesteran dan pada beberapa sisi dinding bangunan dipadukan dengan seng. Material konstruksi pintu dan jendela menggunakan alumunium frame.

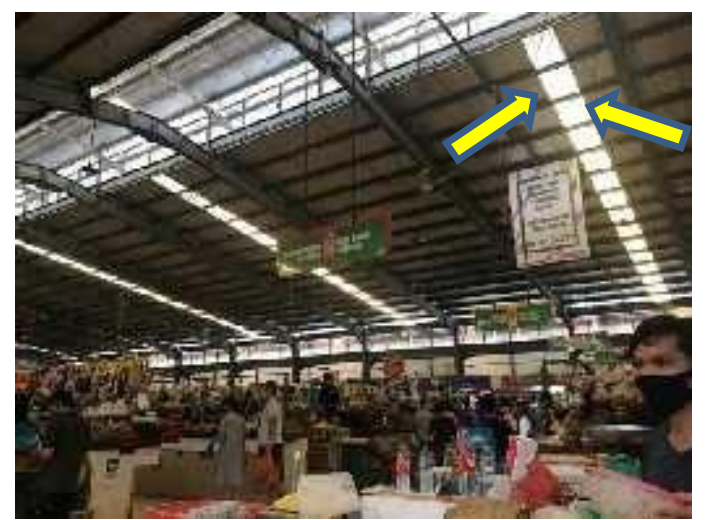

Gambar 6. Penampang sisi atap Pasar Modern Bintaro Sumber: Dokumentasi Pribadi, 2020

Terdapat pula faktor-faktor yang memengaruhi tingkat kapasitas pencahayaan pada suatu bidang kerja, seperti:

1. Letak dan ukuran lubang masuknya cahaya.

2. Hal-hal yang menghalangi bagian muka lubang cahaya.

3. Ukuran teritis.

4. Efek refleksi cahaya di muka bagian dalam ruangan. 


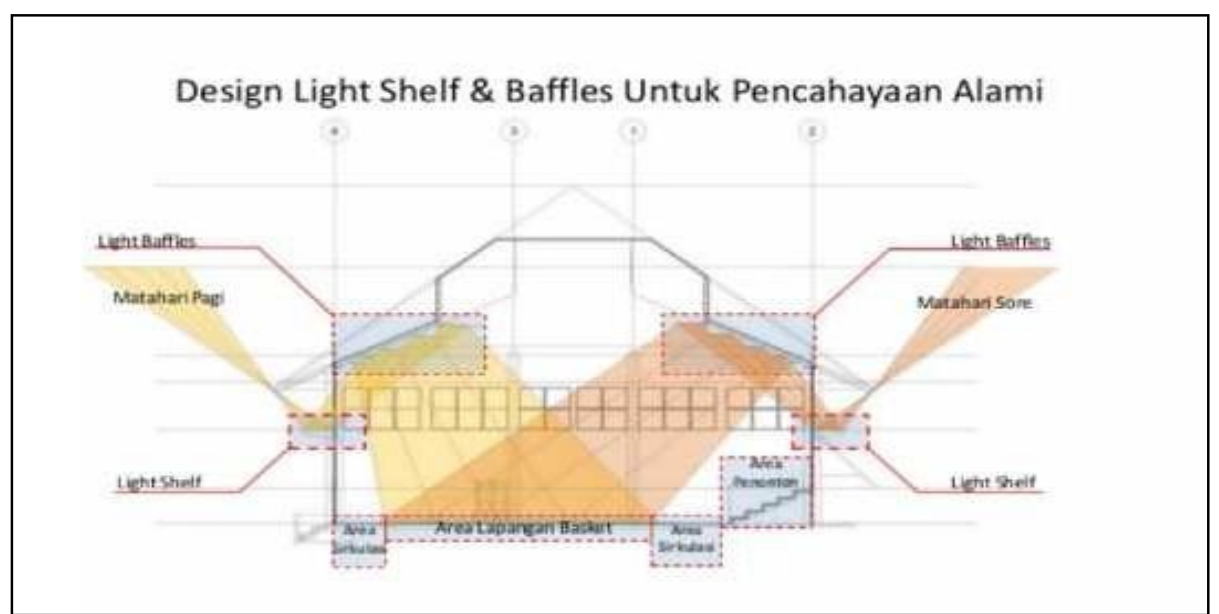

Gambar 7. Sketsa pencahayaan alami dengan konsep yang serupa Sumber: baliagungproperty.com, 2015

3. Memasang ventilasi yang cukup tinggi untuk memudahkan cahaya masuk tepat ke dalam banguan

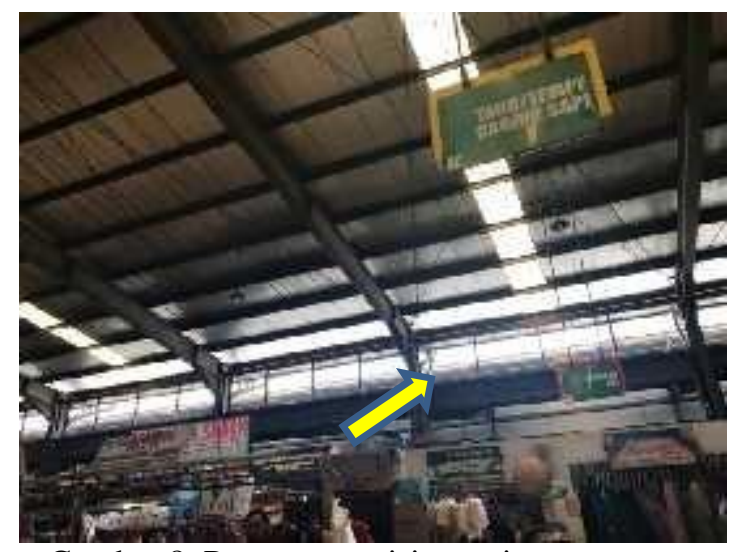

Gambar 8. Penampang sisi samping atap pasar

Sumber: Dokumentasi Pribadi, 2020

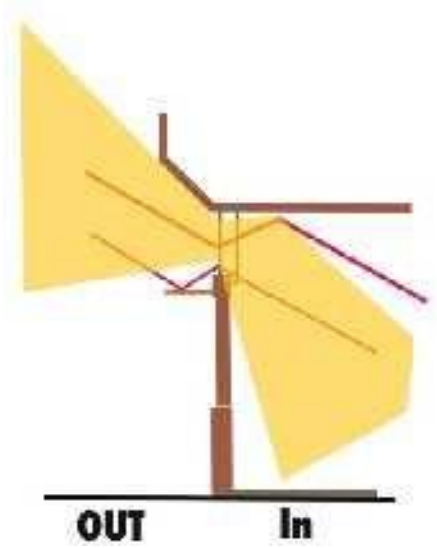

Gambar 9. Sketsa konsep pencahayaan pada ventilasi

Sumber: Hasil Olah Data Penulis, 2020 
4. Pintu masuk yang cukup lebar di setiap sudut mata angin

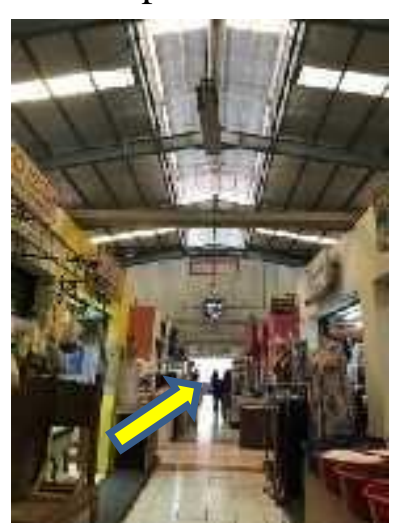

Gambar 8. Penampang salah satu pintu masuk Pasar Modern Bintaro Sumber: Dokumentasi Pribadi, 2020

Meskipun aktivitas pasar berada dalam ruangan yang tertutup dinding, dengan pintu yang relatif besar di setiap sudut mata anginnya memberikan kesan terbuka pada pasar modern ini. Sehingga ruangan tampak tetap terhubung dengan udara luar dan cahaya pun dapat masuk dengan baik.

Gedung pusat pelayanan perbelanjaan Pasar Modern Bintaro merupakan wujud eksplorasi dari model pasar tradisional yang dimodernisasikan. Dengan desain pemecahan masalah pada pasar tradisional, membentuk bangunan pasar modern yang lebih bersih dan tertata, namun tidak menghilangkan budaya tradisional yang ada di pasar pada umumnya. Pada rangka atap menggunakan struktur baja ringan, selain karena relatif cepat dan mudah pemasangannya, baja ringan juga merupakan rangka atap yang anti rayap serta lambat dalam menyalurkan api dan tidak memerlukan perawatan khusus. Kelemahannya sendiri pada harganya yang relatif mahal.

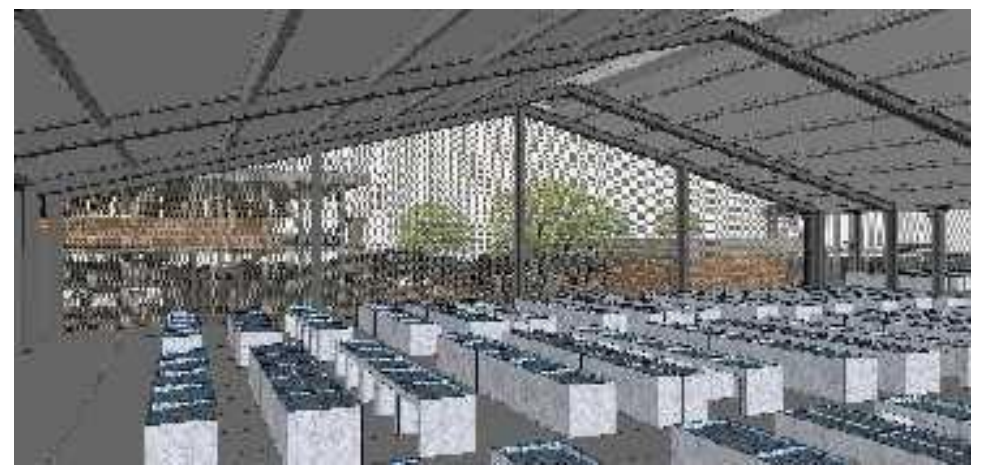

Gambar 8. Gambaran perspektif dalam Pasar Modern Bintaro Sumber: Hasil Olah Data Penulis, 2020

\section{KESIMPULAN}

Hasil dari penelitian ini mencakup bagaimana sistem perancangan Pasar Modern Bintaro dalam mengoptimalisasikan pencahayaan alami. Dapat disimpulkan bahwa pengoptimalan pencahayaan menitik beratkan pada konsep perancangan terhadap pengkondisian desain, pemilihan material, pengaturan pintu, jendela, dan ventilasi sehingga dapat mengoptimalkan cahaya yang masuk kedalam bangunan. Desain pasar modern sebagai wujud perbaikan dari pasar tradisional demi menciptakan kenyamanan dalam beraktivitas di pasar. Kekurangan dalam penelitian ialah sedikitnya data yang 
diambil sebagai pendukung pernyataan sehingga lebih terfokus pada pengamatan lapangan.

\section{DAFTAR PUSTAKA}

Amin, N. (2011). Optimasi sistem pencahayaan dengan memanfaatkan cahaya alami (Studi kasus lab. elektronika dan mikroprosessor UNTAD). Jurnal Ilmiah Foristek, 1(1).

Bataha, D.W.M., V.A. Kumurur., \& H.H. Karongkong. (2017). Redesain pasar tradisional Bersehati Manado. Arsitektur tropis pesisir. Jurnal Arsitektur Daseng UNSRAT Manado, 6(2), 123-131.

Guntur, B., \& Putro, G.M. (2017). Analisis intensitas cahaya pada area produksi terhadap keselamatan dan kenyamanan kerja sesuai dengan standar pencahayaan. OPSI: Jurnal Optimasi Sistem Industri. 10(2), 115-124. https://doi.org/10.31315/opsi.v10i2.2106.

Pertiwi, R.A. (2018) Perancangan Ulang Pasar Wameo di Kota Baubau, Sulawesi Tenggara. [Skripsi]. Yogyakarta: Fakultas Teknik Universitas Atma Jaya Yogyakarta.

Vidiyanti, C., S.F.D.B. Tambunan., \& Y. Alfian. (2018). Kualitas pencahayaan alami dan penghawaan alami pada bangunan dengan fasade roster (Studi kasus: Ruang sholat Masjid Bani Umar Bintaro). Vitruvian: Jurnal Arsitektur, Bangunan, dan Lingkungan, 7(2), 99-106. 